Article

\title{
Impact of Political Connections on Corporate Environmental Performance: From a Green Development Perspective
}

\author{
Liming Zhang ${ }^{\circledR}$, Fei Ye, Li Yang and Guichuan Zhou * \\ Business School, Sichuan University, Chengdu 610065, China; zhangliming@scu.edu.cn (L.Z.); \\ yf1129780941@163.com (F.Y.); 15310619277@163.com (L.Y.) \\ * Correspondence: zhouguichuan@scu.edu.cn
}

Received: 28 January 2019; Accepted: 19 February 2019; Published: 2 March 2019

check for updates

\begin{abstract}
Employing a sample consisting of Chinese A-share listed companies, this study carries out an empirical research to investigate the influence path of political connections on enterprise environmental performance. The results show a strong positive association between political connections and corporate environmental performance, and green technology innovation plays the mediating role between them. In addition, public participation negatively moderates the relationship between political connections and corporate environmental performance. When the level of public participation is higher, the relationship between political connections and corporate environmental performance becomes weaker.
\end{abstract}

Keywords: political connections; corporate environmental performance; green technology innovation; public participation

\section{Introduction}

In the context of green development, great importance has been attached to environmental responsibility from all sectors [1]. Firms have been forced to implement green practices with the increasing demand of stakeholders to protect the environment while achieving development [2]. Corporate behavior and performance can be significantly affected by political connections, which are deemed to be one of the most vital resources for enterprises [3]. Many scholars are therefore focusing on the impact of political connections on corporate environmental performance. However, studies on the relationship between them are not consistent. Some argue that enterprises with political connections bear more environmental responsibility and show better environmental performance $[4,5]$, whereas others assert that politically connected companies tend to evade environmental regulations and have less environmental investment due to government asylum [6,7]. This dispute leads to the following questions: under the new situation of green development, does the tendency to evade environmental responsibility due to government asylum still exist? Do political connections foster or hinder corporate environmental performance?

In recent years, the trend to apply environmental governance has emerged all over the world [8]. Furthermore, the government has long been considered as a vital actor in achieving environmental goals [9]. Additionally, public awareness and behavior on environmental protection is significantly increasing [10]. The role of public participation in environmental management is increasingly recognized [11]. Public participation on environmental protection will affect company environmental behavior. Generally speaking, a higher level of public participation leads to greater restrictions imposed on the pollution behavior of corporate and more environmental investments [12]. However, previous studies on corporate environmental performance have considered this factor less. Will public 
participation on environmental protection affect corporate environmental performance? And how to influence this? The answer is not clear. From a green development perspective, the challenge for companies is how to run a business in a way that is both profitable and environmentally friendly [13]; green technology innovation is considered a critical approach to helping enterprises get out of the dilemma of "environmental pollution-economic development" [14]. Research from the company level reveals that politically connected firms have significantly higher levels of green technology innovation than those of non-connected firms [15].

Researchers have explored some relationships of the four entities: "political connections", "environmental performance", "public participation", and "green technology innovation", using a theoretical approach. Additionally, we can have a preliminary understanding of the possible relationships among the four entities at the practical level through several typical cases. Table 1 shows the details. Company A is politically connected, while company B is not. Furthermore, their environmental performance is different, which means that political connections may affect the corporate environmental performance. Besides, although both company $\mathrm{B}$ and company $\mathrm{C}$ are politically connected, they differ in their environmental performance. We notice that they are also different on the level of green technology innovation. This may indicate that green technology innovation is an important factor. Moreover, the relationship between political connections and environmental performance changes under distinct degrees of public participation. Based on existing research and the above practical characteristics, political connections can affect environmental performance, and green technology innovation plays an important role in this process. As a social force, public participation may affect the relationship between political connections and environmental performance. Hence, this paper uses green technology innovation as a mediation to explore the mechanism of interaction between political connections and corporate environmental performance from the new perspective of green development. It helps to clarify existing disputes. In addition, the impact of public participation on the relation between political connections and corporate environmental performance has been considered in this study, which can enrich existing studies.

Table 1. A comparison of practical characteristics among typical cases.

\begin{tabular}{ccccc}
\hline Company & $\begin{array}{c}\text { Political } \\
\text { Connections }\end{array}$ & $\begin{array}{c}\text { Green Technology } \\
\text { Innovation }\end{array}$ & $\begin{array}{c}\text { Environmental } \\
\text { Performance }\end{array}$ & $\begin{array}{c}\text { Public } \\
\text { Participation }\end{array}$ \\
\hline A & N & N & L & $\mathrm{L}$ \\
B & Y & Y & H & L \\
C & Y & N & H & H \\
D & N & Y & H \\
\hline
\end{tabular}

Note: $\mathrm{Y}$ indicates that a company has this feature, while $\mathrm{N}$ indicates that a company does not have this feature; $\mathrm{L}$ represents a low level while $\mathrm{H}$ represents a high level; The four companies come from the following research samples, and the relevant data is extracted from the following measurements.

\section{Theoretical Basis}

According to the resource dependence theory (RDT), organizations are depicted as open systems, where the ability to gain critical resources from the outside affects their performance as they are resource-constrained [16]. Various resources are basic influencing factors of enterprise behavior and performance. Resource dependence theory (RDT) suggests that the government is the main source of external resources and opportunities for enterprises [17]. Enterprises rely on political connections in emerging economies, where considerable power and resources affecting business activities have still been controlled by the government [18]. Political connection is regarded as an important external resource. Shaping interactions with regulators and political decision-makers via political strategies helps companies gain various benefits, including government subsidies, reduced exposure to risk and preferential treatment by government-controlled banks [19-21]. Moreover, the logic of the resource dependence theory suggests that the resource allocation of an enterprise will affect its ability to apply innovation [22]. 
Based on the resource dependence theory, politically-connected companies have a sufficient capacity to invest in innovation due to the strong resource base. In the context of green development, more attention is paid to the environmental performance of enterprises, urging enterprises to carry out environmental management. In addition, pollution prevention is deemed an important strategy for achieving a competitive advantage [23]. Therefore, under the influence of resource advantage and environmental pressure, politically connected enterprises tend to carry out environment-related innovation: green technology innovation. It is known that innovation is an effective way to improve enterprise performance [24]. As a result, corporate environmental performance can be enhanced through green technology innovation.

Institutional theory combines business behavior with social norms and values, which promotes organizations to rationalize their business [25]. According to the institutional theory, the public, government and society are all institutional constituents, imposing pressures on enterprises to engage in green behaviors in order to maintain their legitimacy [26]. Institutional forces include formal and informal pressures imposed on the organization, and public participation can be defined as an informal institutional force. As a driving force coming from externalities, public concern imposes a considerable effect on corporate environmental management and environmental strategy [27]. The institutional theory suggests that companies with legitimate incentives pay more attention to their influential stakeholders [28]. Furthermore, it is imperative for them to respond to the desires and pressures of stakeholders. In the context of green development, the company is under pressure to go green for the sake of the expectations of eco-friendly key stakeholders [29]. Therefore, as an important part of the institutional constituents, the public exerts influence on corporate environmental behavior, which provides an opportunity for us to discuss the moderating effect of public participation.

\section{Hypothesis and Theoretical Model}

\subsection{Political Connections and Corporate Environmental Performance}

A majority of studies have provided support for the positive relationship between political connections and corporate environmental performance. Access to green subsidies can be obtained through political connections [30], which provide financial incentives for companies to implement government environmental policies and improve their environmental performance [31]. Based on the resource dependence theory, Lin et al. (2015) confirmed that a greater environmental performance can be achieved in politically connected companies owing to green subsidies [4]. In addition, Wang et al. (2018) pointed out that political connections are positively associated with green investment [32]. Politically connected companies are motivated to employ green practices as they have received key resources through political connections [30]. Thus, firms with political connections have better environmental performances.

Despite this, several scholars point out that political connections and corporate environmental performance are negatively correlated. Morgan (2013) held that close ties between business and government provide opportunities for enterprises to evade emissions regulations [33]. In this respect, political connections may act like an umbrella of protection, providing convenience in some cases for enterprises to avoid environmental responsibility [5]. Moreover, firms with a poor environmental performance are more enthusiastic about political activities [34], which provides support for the negative relationship between political connections and environmental performance.

However, things are different under the green development trend. Currently, the government in emerging economies plays an important role in promoting green development. Governments around the world have begun to take a variety of methods to control or reduce pollution [35]. A series of related measures have been launched, including introducing green technology, initiating green initiatives, and even directly integrating environmental management into the national development planning as well as the national project [36]. Besides, Green GDP (Green Gross Domestic Product, a comprehensive indicator involving the environment and economy to evaluate sustainable development) and other environmental protection policies are implemented to urge local governments to fulfill their 
environmental responsibilities [37]. In this context, the government is unlikely to indulge companies who evade their environmental responsibility. Guo et al. (2018) also found that after incorporating environmental protection into the official assessment system, companies with political connections have increased their environmental investment [38]. Therefore, from the green development perspective, even companies with political connections cannot escape environmental responsibility and may undertake it more. Summarizing the above arguments, we hypothesize the following.

Hypothesis 1. Political connection is positively associated with corporate environmental performance.

\subsection{Political Connections and Green Technology Innovation}

Previous research has demonstrated the positive relationship between political connections and technological innovation. For example, Khwaja and Mian (2005) confirmed that political connections have a positive effect on corporate R\&D [39]. Shi and Zhu (2014) also pointed out that politically connected firms have significantly higher levels of green technology innovation than those of non-connected firms [15]. Nanda and Rhodes-Kropf (2013) argued that political connections provide companies with a higher probability of success in innovation, as they help to avoid potential risks in the process of innovation [40]. In the context of green development, green technology innovation is the key activity for enterprises to implement environmental management. Resource is the most fundamental among the factors influencing green technology innovation. Political connection is a special key resource in emerging markets and provides access to subsidies, favorable regulation and government contracts [3], which contribute to enterprise technology innovation. Lin et al. (2014) pointed out that political connections can lead to a greater performance in green innovation owing to financial capital and preferential policies about green innovation [41]. Therefore, we propose the following hypothesis.

Hypothesis 2. Political connection is positively associated with green technology innovation.

\subsection{Political Connections, Green Technology Innovation and Corporate Environmental Performance}

From previous studies, political connections have a positive impact on technological innovation [39]. Politically connected firms usually have sufficient resources for green technology innovation. For example, a series of resource advantages can be obtained through political connections, including relevant supporting policies, tax exemptions and easily-accessible subsidies, which are beneficial for investing into green innovation [3]. Meanwhile, green technology innovation has an important impact on environmental performance. The differences in environmental performances can be attributed to the heterogeneity of green technology innovation levels [42]. Green technology innovation enables companies to balance their production and environmental goals, meeting the demands of stakeholders [43]. In addition, Singh et al. (2016) pointed out that green innovation motivates enterprises to actively participate in environmental practices [44]. Therefore, high levels of green technology innovation can bring about a better corporate environmental performance. In summary, companies with political connections often invest more in green technology innovation, resulting in a better environmental performance. Hence, the following hypothesis can be deduced.

Hypothesis 3. Green technology innovation has a mediating effect on the relationship between political connections and corporate environmental performance. 


\subsection{Political Connections, Public Participation and Corporate Environmental Performance}

Political connection is not only a special resource for firms, but also a kind of constraint and supervision. Politically connected enterprises are given more social responsibility and higher expectations in exchange for the benefit derived from political connections. [45]. Companies will actively fulfill their social responsibilities to strengthen the bond effect of political connections. In the context of green development, the Chinese government has incorporated environmental indicators into the local government assessment, and political connections will strengthen the influence of political achievement requirements on corporate social responsibility behavior [46]. Thus, the pressure brought about by political connections motivates firms to act in environmentally responsible ways [5]. Meanwhile, as an external supervisory force, public participation exerts an environmental pressure on enterprises and limits the pollution behavior of firms [12]. Besides, public participation plays a positive role in monitoring corporate pollution emissions and is a beneficial supplement to government supervision [47]. In summary, similar to political connections, public participation is another constraint mechanism that affects the corporate environmental performance; the following hypothesis can be deduced.

Hypothesis 4. Public participation moderates the relationship between political connections and the corporate environmental performance.

As shown in Figure 1, this study establishes the theoretical model. The model shows the main variables that this article focuses on and the relationships between them. In addition, it demonstrates the influence path of political connections on the enterprise environmental performance.

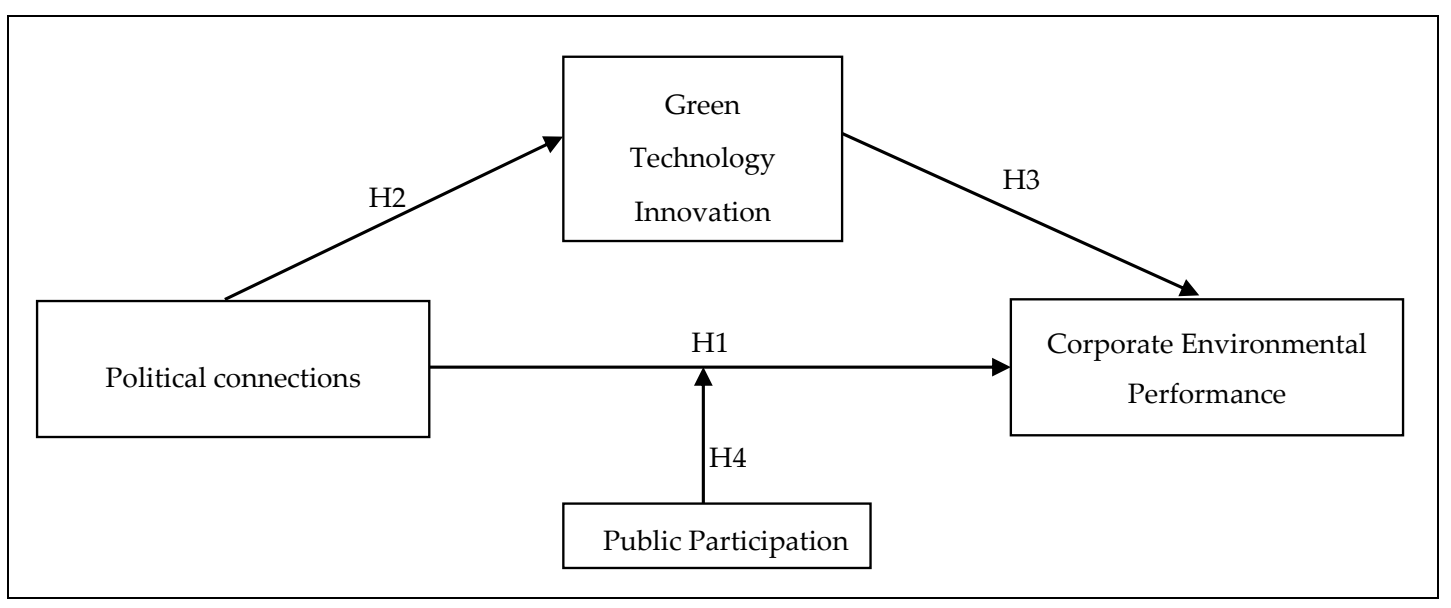

Figure 1. Theoretical model of how political connections affect corporate environmental performance.

\section{Research Method}

\subsection{Dependent Variables Measurement}

The corporate environmental performance represents the performance of companies in fulfilling their environmental responsibility [48]. It refers to the level of improvement a company reaches in its environmental responsibility $[49,50]$. Several studies which relied on the toxic release inventory (TRI) database have typically used pollutant release as a proxy for corporate environmental performance [51-53]. But research on environmental performance is restricted by data availability [54]. Research from China cannot replicate this method due to the lack of relevant databases and the limited disclosure of environmental information. Walls et al. (2012) constructed the indicators of environmental strengths and concerns to investigate the link between corporate governance and environmental performance [55]. This is a beneficial inspiration for assessing environmental performance in the Chinese setting. 
Therefore, we use environmental strengths and concerns to construct the measure of corporate environmental performance. In the concrete operation, following Turban and Greening (1997), we code according to the extent of environmental strengths and concerns, and a firm's score is the sum of its concern and strength ratings [56]. Therefore, scores could range from -2 to +4 . Based on the existing research, the following aspects have been taken into consideration as specific subcategories: ISO14001 certifications, environmental awards, self-reported corporate efforts to mitigate the environmental impacts, the title of National Environmentally Friendly Enterprise, and environmental violation [57,58]. Table 2 provides details of the measurements for corporate environmental performance.

Table 2. The measurement of corporate environmental performance.

\begin{tabular}{ccc}
\hline Dimension & Specific Subcategories & Code \\
\hline \multirow{2}{*}{ Environmental strengths } & The title of National Environmentally Friendly Enterprise & 1 \\
& ISO14001 certifications & 1 \\
& Environmental awards & 1 \\
Environmental concerns & Self-reported corporate efforts to mitigate the environmental & 1 \\
\hline
\end{tabular}

\subsection{Independent Variables Measurement}

\subsubsection{Political Connections}

Political connections refer to the fact that the chief executive officer (CEO) of a company is a current or former government official [59]. In view of Chinese social circumstances, we define a private company as having political connections if its controller or top manager has political experience [4]. Unlike previous studies from China, the comprehensiveness of the sample is taken into account. The research covers companies with different ownerships and distinguishes the strength of their political connections. In China, state-owned enterprises have direct political connections due to their peculiar ownership and management systems [31]. The chairman and executive team of state-owned enterprises are directly appointed by the government; thus their political connections are stronger than those of private enterprises [60]. Hence, in this study, state-owned firms are given 2, private firms defined as being politically connected are given 1 , and other firms are given 0 .

\subsubsection{Green Technology Innovation}

Different from traditional technology innovation, green technology innovations put more emphasis on cyclic utilization, low energy consumption and cleaner production [61]. Some scholars use energy consumption, green patents and pollution intensity to measure green technology innovation based on the perspective of the output $[62,63]$. From the perspective of the input, studies generally employ Green R\&D to evaluate a company's green technology innovation $[64,65]$. In view of the availability of reliable data at a firm level and the purpose of our study, we select the perspective of input. In this study, the Green R\&D is used as a proxy for green technology innovation. The Green $R \& D$ is a firm's R\&D expenditure aimed at environmental measures [64]. Therefore, we manually screen and count the company's Green R\&D projects. Following Cormier and Magnan (2015), we select Green R\&D projects based on relevant keywords, such as "green", "sustainable", "clean", "energy saving", "environmental", etc [66]. The value of Green R\&D is calculated by aggregating the values of each item. Referring to Guo et al. (2018), we take the natural logarithm of the R\&D expenditure to scale the variable [67].

\subsubsection{Public Participation}

Public participation in environmental issues represents the extent to which the public supervises environmental pollution and participates in environmental protection. Since the impact of public 
participation on environmental governance takes a certain period of time [68], we select data from the last year to capture the real impact on the current period. Referring to Yang et al. (2018), this study employs indicators from the China Environmental Yearbook to measure public participation, including the number of letters and visitors, the batch of visitors, proposals of the National People's Congress (NPC) and the Chinese People's Political Consultative Conference (CPPCC) about environmental issues from various regions in 2015 [12]. Following this, comprehensive indicators can be obtained through standardized processing and weighting. The greater the value of this indicator, the higher the level of public participation.

\subsection{Control Variables Measurement}

Following Ye et al. (2016), the firm size and profitability are selected as control variables [6]. The reason for this is that larger companies tend to have more environmental management. Moreover, companies with a high profitability have a better growth and are more likely to bear environmental responsibility. Specifically, the natural logarithm of the total assets at the end of the year represents the firm size, and return on assets (ROA) is selected as a proxy indicator of profitability. In addition, the data on the control variables all come from the China Stock Market and Accounting Research (CSMAR) database.

\subsection{Regression Model}

In this study, the ordinary least square (OLS) regression analysis is used to explore the relationship between variables. In order to test our hypotheses, the following regression models are employed in this study:

$$
\begin{gathered}
\text { CEP }=\alpha+\beta_{1} \mathrm{PC}+\beta_{2} \mathrm{SIZE}+\beta_{3} \mathrm{ROA}+\varepsilon \\
\mathrm{GTI}=\alpha+\beta_{1} \mathrm{PC}+\beta_{2} \mathrm{SIZE}+\beta_{3} \mathrm{ROA}+\varepsilon \\
\mathrm{CEP}=\alpha+\beta_{1} \mathrm{PC}+\beta_{2} \mathrm{GTI}+\beta_{3} \mathrm{SIZE}+\beta_{4} \mathrm{ROA}+\varepsilon \\
\mathrm{CEP}=\alpha+\beta_{1} \mathrm{SIZE}+\beta_{2} \mathrm{ROA}+\varepsilon \\
\mathrm{CEP}=\alpha+\beta_{1} \mathrm{PC}+\beta_{2} \mathrm{PP}+\beta_{3} \mathrm{SIZE}+\beta_{4} \mathrm{ROA}+\varepsilon \\
\mathrm{CEP}=\alpha+\beta_{1} \mathrm{PC}+\beta_{2} \mathrm{PP}+\beta_{3} \mathrm{PC}{ }^{*} \mathrm{PP}+\beta_{4} \mathrm{SIZE}+\beta_{5} \mathrm{ROA}+\varepsilon
\end{gathered}
$$

where CEP stands for the corporate environmental performance, GTI stands for green technology innovation, PC indicates the degree of political connections and PP represents the level of public participation. SIZE and ROA are two control variables related to the firm characteristics, representing enterprise size and profitability, respectively. $\alpha$ represents the intercept, and $\varepsilon$ is the error term. Following this, the regression models (1) to (3) are constructed to examine Hypotheses 1 to 3 presented in this research, while regression models (4) to (6) are constructed to test Hypothesis 4 . The brief descriptions of the variables are shown in Table 3. Through the operation of the relevant measurements, each variable is a value that can be directly observed and compared without unit. 
Table 3. The brief descriptions of the variables.

\begin{tabular}{|c|c|c|}
\hline Variables & Abbreviation & Explanation \\
\hline $\begin{array}{l}\text { Corporate environmental } \\
\text { performance }\end{array}$ & CEP & $\begin{array}{l}\text { The performance of companies in fulfilling their environmental } \\
\text { responsibility, measured by the sum of the scores about the environmental } \\
\text { strengths and environmental concerns. }\end{array}$ \\
\hline Political connections & PC & $\begin{array}{c}\text { The state-owned enterprise is assigned a value of } 2 \text {; the private firm } \\
\text { defined as being politically connected is assigned a value of } 2 \text {; and other } \\
\text { firms are assigned a value of } 0 .\end{array}$ \\
\hline $\begin{array}{l}\text { Green technology } \\
\text { innovation }\end{array}$ & GTI & $\begin{array}{c}\text { Technological innovation input on environmental issues, represented by } \\
\text { green R\&D. }\end{array}$ \\
\hline Public participation & PP & $\begin{array}{l}\text { The extent to which the public supervises environmental pollution and } \\
\text { participates in environmental protection, measured by the number of } \\
\text { petitions and proposals about environmental issues from various regions. }\end{array}$ \\
\hline Firm size & SIZE & The natural logarithm of the total assets at the end of the year. \\
\hline Return on assets & ROA & $\begin{array}{l}\text { ROA equals net profit/average total assets, representing the profitability of } \\
\text { a company. }\end{array}$ \\
\hline
\end{tabular}

\subsection{Data Collection and Sample}

To study the corporate environmental performance, companies in these industries (finance, public utilities, real estate, and business) are eliminated, because they hardly produce environmental pollution. To test our hypotheses, especially the intermediary role of green technology innovation, we focus on Chinese A-share listed companies that have disclosed information about their project R\&D expenditure. In China, listed companies are not forced to disclose the specific $R \& D$ expenditure of projects. But some volunteer to disclose this through the annual reports, which provides an opportunity for us to explore the mechanism of action between political connections and corporate environmental performance. We therefore exclude the companies without information about any specific R\&D expenditures. Then, we delete cases with missing values and unstable operations. As a result, our final sample includes 157 companies.

All the research data in this paper is public data, and we chose 2016 as the time point of observation. ISO14001 certification can be found on the website of the China National Certification and Accreditation Administration. The National Environmentally Friendly Enterprise is confirmed by the Ministry of Ecology and Environment of China. The data about environmental awards and companies' efforts to mitigate the environmental impacts are obtained from the annual reports of listed companies. The public participation index comes from the China Environment Yearbook. The rest of the data are collected from the CSMAR database.

\section{Empirical Results and Analysis}

\subsection{Descriptive Statistics}

Table 4 reports the descriptive statistics for all variables employed in this study. The maximum value of the political connections indicator is 2 , and the average value is 1.255 , which indicates that the samples are mostly politically related. As for green technology innovation, the maximum value is 8.966 , and the maximum value is 19.789 , which means that the gap between the companies on green technology innovation is large. The maximum value of public participation is 0.152 , and the average value is 0.053 , which indicates a low degree of public participation among samples. The value of the corporate environmental performance varies from -1 to 3 , representing great differences in environmental performance between the firms. Regarding the control variables, the average of the firm size is 22.470 , showing that the companies are mostly large-scale. The standard deviation of the return on assets (ROA) is 0.048 , which represents a low degree of deviation on profitability. 
Table 4. Descriptive statistics.

\begin{tabular}{cccccc}
\hline Variables & Sample & Min & Max & Mean & Std \\
\hline PC & 157 & 0 & 2 & 1.255 & 0.706 \\
GTI & 157 & 8.966 & 19.785 & 15.034 & 1.715 \\
PP & 157 & 0 & 0.152 & 0.053 & 0.040 \\
CEP & 157 & -1 & 3 & 1.210 & 0.809 \\
Size & 157 & 20.153 & 26.365 & 22.470 & 1.174 \\
ROA & 157 & -0.190 & 0.161 & 0.024 & 0.048 \\
\hline
\end{tabular}

\subsection{Mediating Effect Analysis}

Referring to Wen and Ye (2014), we employ a hierarchical regression analysis in this study to test the mediating effect [69], and three models have been established. The regression results are shown in Table 5 below. Both Model 1 and Model 3 use the corporate environmental performance (CEP) as the dependent variable. Model 1 is estimated using political connections (PC) and the control variables as explanatory variables. Meanwhile, green technology innovation (GIT) is included in Model 3. In order to verify the relationship between PC and GIT, Model 2 uses GTI as the dependent variable. According to the regression model, the maximum value of the variance inflation factor (VIF) for all variables is 1.286 , which indicates that there is no collinearity issue.

Table 5. Regression model of the mediating effect.

\begin{tabular}{|c|c|c|c|c|c|c|}
\hline \multirow{3}{*}{ Variables } & \multicolumn{2}{|c|}{ CEP } & \multicolumn{2}{|c|}{ GTI } & \multicolumn{2}{|c|}{ CEP } \\
\hline & \multicolumn{2}{|c|}{ Model 1} & \multicolumn{2}{|c|}{ Model 2} & \multicolumn{2}{|c|}{ Model 3} \\
\hline & $\beta$ & VIF & $\beta$ & VIF & $\beta$ & VIF \\
\hline SIZE & $0.166^{* *}$ & 1.204 & $0.229 * * *$ & 1.204 & 0.126 & 1.267 \\
\hline ROA & $0.169^{* *}$ & 1.033 & -0.038 & 1.033 & $0.176^{* *}$ & 1.035 \\
\hline PC & $0.359^{* * *}$ & 1.213 & $0.247^{* * * *}$ & 1.213 & $0.317^{* * *}$ & 1.286 \\
\hline GTI & & & & & $0.173 * *$ & 1.200 \\
\hline $\mathrm{R} 2$ & \multicolumn{2}{|c|}{0.206} & \multicolumn{2}{|c|}{0.166} & \multicolumn{2}{|c|}{0.231} \\
\hline Adj R2 & \multicolumn{2}{|c|}{0.191} & \multicolumn{2}{|c|}{0.150} & \multicolumn{2}{|c|}{0.211} \\
\hline $\mathrm{F}$ & \multicolumn{2}{|c|}{$13.254^{* * *}$} & \multicolumn{2}{|c|}{$10.180^{* * *}$} & \multicolumn{2}{|c|}{$11.422^{* * *}$} \\
\hline
\end{tabular}

Note: ${ }^{*} \mathrm{p}<0.1,{ }^{* *} \mathrm{p}<0.05,{ }^{* * *} \mathrm{p}<0.01$, all tests are two-tailed; $\mathrm{N}=157$.

As Model 1 shows, there is a significant positive correlation between the political connections and the corporate environmental performance $(\beta=0.359, p<0.01)$, and Hypothesis 1 is supported. This indicates that companies with political connections have a better environmental performance, which can be attributed to the greater environmental responsibility brought about by political connections, especially in the context of green development. Furthermore, Hypothesis 2 is verified in Model 2. The results in Model 2 show that the political connection is positively associated with green technology innovation $(\beta=0.247, \mathrm{p}<0.01)$. This is consistent with the conclusions in Shi and Zhu (2014), as well as and Lin et al. (2014) [15,41]. Companies with political connections have a higher investment in green technology innovation due to the resource advantages brought about by political connections. In summary, we have verified the positive relationship between the independent variable and dependent variable, as well as the positive correlation between the independent variable and moderating variable, through Models 1 and 2.

Once green technology innovation is added in Model 3, R2 jumps to 0.231 in Model 3 from 0.206 in Model 1, which indicates a stronger explanatory power from Model 3. This means that green technology innovation is a significant predictor of corporate environmental performance. The results in Model 3 show that the regression coefficients of political connections $(\beta=0.317, \mathrm{p}<0.01)$ and green technology innovation $(\beta=0.173, p<0.05)$ are both positive and statistically significant, providing strong support for Hypothesis 3. Green technology innovation plays a partial intermediary role between political connections and corporate environmental performance. Political connections would bring resource 
advantages and more environmental responsibilities to companies and promote companies to invest in green technology innovation, which in turn helps to increase the environmental performance of firms.

Focusing on the impact of company characteristics on environmental performance, the results in Model 2 show that size is positively associated with GTI $(\beta=0.229, \mathrm{p}<0.01)$. This means that larger companies have higher levels of green technology innovation because they have sufficient resources to invest. In addition, we found that the regression coefficients of ROA are both positive and statistically significant in Model $1(\beta=0.169, \mathrm{p}<0.05)$ and Model $3(\beta=0.176, \mathrm{p}<0.05)$, suggesting that companies with a higher profitability have a better environmental performance. The possible reason for this is that companies with a high profitability have promising future and pay more attention to sustainable development, as a result of which they would actively engage in environmental management.

\subsection{Moderating Effect Analysis}

To test the moderating effect, a hierarchical regression analysis is employed in this study. Table 6 reports the results of the regression analysis. Model 4 contains the control variables only. Political connections and public participation variables are added in Model 5. Model 6 adds the interactions between political connections and public participation. The analysis results show that, except for the interaction term, the variance inflation factor (VIF) of each variable is under 4, which explains that there is no collinearity issue.

Table 6. Regression model of the moderating effect.

\begin{tabular}{|c|c|c|c|c|c|c|}
\hline \multirow{3}{*}{ Variables } & \multicolumn{6}{|c|}{ CEP } \\
\hline & \multicolumn{2}{|c|}{ Model 4} & \multicolumn{2}{|c|}{ Model 5} & \multicolumn{2}{|c|}{ Model 6} \\
\hline & $\beta$ & VIF & $\beta$ & VIF & $\beta$ & VIF \\
\hline SIZE & $0.306^{* * *}$ & 1.019 & $0.169 * *$ & 1.207 & 0.140 * & 1.240 \\
\hline ROA & 0.131 * & 1.019 & $0.170 * *$ & 1.033 & $0.170 * *$ & 1.033 \\
\hline PC & & & $0.345^{* * *}$ & 1.218 & $0.578^{* * *}$ & 3.195 \\
\hline PP & & & 0.073 & 1.004 & $0.319 * *$ & 3.383 \\
\hline $\mathrm{PC}^{*} \mathrm{PP}$ & & & & & $-0.370 * *$ & 5.404 \\
\hline $\mathrm{R} 2$ & \multicolumn{2}{|c|}{0.100} & \multicolumn{2}{|c|}{0.212} & \multicolumn{2}{|c|}{0.237} \\
\hline Adj R2 & \multicolumn{2}{|c|}{0.088} & \multicolumn{2}{|c|}{0.191} & \multicolumn{2}{|c|}{0.212} \\
\hline $\mathrm{F}$ & \multicolumn{2}{|c|}{$8.539^{* * *}$} & \multicolumn{2}{|c|}{$10.199 * * *$} & \multicolumn{2}{|c|}{$9.377^{* * *}$} \\
\hline
\end{tabular}

Note: ${ }^{*} \mathrm{p}<0.1,{ }^{* *} \mathrm{p}<0.05,{ }^{* * *} \mathrm{p}<0.01$, all tests are two-tailed; $\mathrm{N}=157$.

Once political connections and public participation are added in Model 5, R2 jumps to 0.212 from 0.100. Additionally, after adding the interaction, $\mathrm{R} 2$ in Model 6 reaches 0.237 . As the regression data shows, political connection is positively associated with corporate environmental performance $(\beta=0.345, p<0.01)$. In addition, the regression coefficient of public participation is positive, significant in Model 6, but not significant in Model 5. This means that public participation cannot predict the corporate environmental performance separately, but that it has a significant effect on corporate environmental performance by interacting with other variables.

In the analysis of the results, the test of the moderating effect does not require the main effect to be significant [70]. If the regression coefficient of the interaction is significant, the moderating effect exists [71]. As can be seen from Model 6, public participation significantly regulates the relationship between political connections and corporate environmental performance $(\beta=-0.370$, $\mathrm{p}<0.05$ ). This provides support for Hypothesis 4 . When the level of public participation is high, the relationship between political connections and corporate environmental performance is weakened. It is known that the pressure of environmental responsibility brought about by political connections has prompted companies to conduct active environmental management. Moreover, a higher degree of public participation means that the public has more supervision over the environmental behaviors of companies. Therefore, whether companies have political connections or not, they must act in 
environmentally responsible ways. At this time, public participation plays a general supervisory role, and the constraint of environmental responsibility brought about by political connections is weakened.

\subsection{Robustness Tests}

To confirm the general pattern of conclusions in this study, supplemental analyses are conducted to increase the robustness of the results. First, following Ye et al. (2016) and Zhang Cui (2017), we replicate our regression analysis employing the CEP index obtained by the J-F coefficient method as an alternative measure of the CEP $[5,6]$. Specifically, the corporate environmental performance index (CEPI) is calculated using the following formulas:

$$
\mathrm{CEPI}= \begin{cases}\frac{\mathrm{p}^{2}-p \times|q|}{r^{2}}, & \text { if } \mathrm{p}>|\mathrm{q}| \\ 0, & \text { if } \mathrm{p}=|\mathrm{q}| \\ \frac{p \times|q|-\mathrm{q}^{2}}{r^{2}}, & \text { if } \mathrm{p}<|\mathrm{q}| \\ \mathrm{r}=\mathrm{p}+|q| & \end{cases}
$$

where p equals the scores of the environmental strengths, and q equals the scores of the environmental concerns.

Additionally, to further verify the robustness of the above regression results, we control the impact of firm age (AGE) and the independent directors ratio (INDR) on the corporate environmental performance, adding two control variables. The firm age represents the number of years since the firm was listed. The independent directors ratio determines the supervision level of the listed companies to some extent [72]. However, the coefficient of the INDR is not significant, indicating that the actual supervision of INDR is weak, especially in terms of the environment. We found that the regression coefficient of the AGE is negative and statistically significant. The possible reason for this is that younger firms are more likely to take part in green investment since they need greater legitimacy [32]. As shown in Table 7, the relationships between the main variables is basically consistent with the previous results, providing evidence to support the fact that our conclusions are robust.

Table 7. Robustness tests.

\begin{tabular}{ccccccc}
\hline \multirow{2}{*}{ Variables } & CEPI & GTI & CEPI & CEPI & CEPI & CEPI \\
\cline { 2 - 6 } & Model 1 & Model 2 & Model 3 & Model 4 & Model5 & Model 6 \\
\hline SIZE & 0.112 & $0.247^{* * *}$ & 0.078 & $0.222^{* * *}$ & 0.115 & 0.066 \\
ROA & 0.092 & -0.065 & 0.101 & 0.085 & 0.091 & 0.099 \\
AGE & $-0.316^{* * *}$ & -0.082 & $-0.305^{* * *}$ & $-0.204^{* *}$ & $-0.323^{* * *}$ & $-0.298^{* * *}$ \\
INDR & $-0.071^{* *}$ & -0.085 & -0.059 & -0.107 & -0.069 & $-0.057^{* * *}$ \\
PC & $0.362^{* * *}$ & $0.262^{* * *}$ & $0.326^{* * *}$ & & $0.361^{* * *}$ & $0.691^{* * *}$ \\
GTI & & & $0.135^{*}$ & & & \\
PP & & & & & 0.037 & $0.403^{* * *}$ \\
PC PP & & & & & 0.185 & $0.246^{* * *}$ \\
R2 & 0.184 & 0.179 & 0.199 & 0.088 & 0.185 & 0.206 \\
Adj R2 & 0.157 & 0.152 & 0.167 & 0.064 & 0.153 & $6.783^{* * *}$ \\
F & $6.799^{* * *}$ & $6.581^{* * *}$ & $6.203^{* * *}$ & $3.651^{* * *}$ & $5.679 * *$ &
\end{tabular}

Note: ${ }^{*} \mathrm{p}<0.1,{ }^{* *} \mathrm{p}<0.05,{ }^{* * *} \mathrm{p}<0.01$, all tests are two-tailed; $\mathrm{N}=157$.

\section{Discussion}

This research has examined three issues concerning the relationship between political connections and corporate environmental performance, including (1) how corporate environmental performance relates to political connections; (2) What role green technology innovation plays in their relationship; and (3) whether there is a change in the relationship between political connections and corporate environmental performance when there is a high level of public participation. Using the data of Chinese listed companies in 2016, we demonstrate the significant positive relationship between political 
connections and corporate environmental performance, which supports Hypothesis 1. Our empirical results show that politically connected firms generally have a higher environmental performance, which is consistent with the results of previous studies $[4,5]$.

However, previous scholars used the data of Chinese listed companies before 2014 to study the relationship between political connections and corporate environmental performance, and pointed out that political connections would become an umbrella of protection for enterprises to evade environmental responsibility [6]. This is inconsistent with the conclusion of our study, and it may be attributed to the transformation of the development model in China. In the past three years, abandoning the previous extensive development, China has been actively building beautiful China and requiring green development. In this context, storms of pollution control are sweeping the country. The government attaches great importance to environmental protection and implements environmental protection supervision on a nationwide scale, where enterprises are the key targets for monitoring. Therefore, even companies with political connections cannot escape environmental responsibility. Meanwhile, the government aims for environmental governance under the perspective of green development, and political connections will strengthen the influence of political achievement demands on corporate social responsibility behavior [46]. Thus, the government would transfer environmental responsibility to companies closely related to them. Politically connected companies bear more environmental responsibilities and have a higher environmental performance with the support of government green subsidies.

Model 2 in Table 5 shows that political connection is positively associated with green technology innovation, supporting Hypothesis 2. Based on the resource dependence theory, politically connected firms generally have sufficient resources to invest in innovation and have a high level of green technology innovation, which in turn helps to increase the environmental performance of firms. This also provides support for Hypothesis 3.

Additionally, Table 5 shows that green technology innovation plays a mediating role in the relationship between political connections and corporate environmental performance, which is also consistent with Hypothesis 3 . As can be seen from the above, politically related companies assume more environmental responsibilities in the context of green development, which requires them to operate in a more environmentally friendly way. This therefore strengthens technological innovation and process improvement to reduce pollution emissions and enhance energy efficiency. Furthermore, politically connected companies have more opportunities to receive scarce and valuable resources, such as government grants, subsidies and tax reductions related to environment protection [3]. As a result of this, politically connected companies perform better in green technology innovation. Simultaneously, empirical evidence reveals the role of green technology innovation in improving environmental performance [42]. In conclusion, political connections promote green technology innovation, which is beneficial to corporate environmental performance.

Table 6 shows that public participation negatively moderates the relationship between political connections and corporate environmental performance, supporting Hypothesis 4 . When the level of public participation is higher, the relationship between political connections and corporate environmental performance becomes weaker. Public participation is an effective measure for reducing environmental pollution, and it promotes environmental governance by supervising corporate pollution emissions and actively interacting with the government departments related to environmental protection [73]. In the context of green development, political connections endow specific companies with more environmental responsibility [5]. Nevertheless, public participation is a universal constraint mechanism that monitors the performance of environmental responsibility of all participants in market economic activities. High public participation represents the strong supervision of corporate environmental behavior from the public. Therefore, whether companies have political connections or not, they must act in environmentally responsible ways. At this time, public participation plays a general supervisory role, and the constraint of environmental responsibility brought about by political 
connections is weakened. Thus, when public participation is high, the relationship between political connections and environmental performance is not as strong as before.

The environment may be viewed as a resource providing indispensable services for the economy and for human life [74]. Compared to the individual, a company exerts a greater influence on the environment due to its larger size. Great improvements on the environment will be achieved if every enterprise actively assumes its environmental responsibility. Therefore, it is of great significance to study the environmental performance of enterprises. Beyond urging companies to implement green practices from the perspective of responsibility and supervision, the economic evaluation of the environmental services valuation is another effective approach, given that benefit is still the main motivation for companies to engage in environmental behavior. Moreover, Kyriakopoulos et al. (2017) indicated that ecosystems services valuation contributes to solving the dilemma of sustainable practices companies, as it helps them balance environmental values and business interests [74]. As a result, more corporate environmental behaviors, such as green technology innovations, converge and promote environmental improvement. To some extent, business-based behavior can also be a specific part of the implementation of environmental responsibility.

\section{Conclusions}

The theoretical contribution of this study is mainly reflected in three aspects. First, adopting a new research perspective, we re-examined the relationship between political connections and corporate environmental performance from the perspective of green development, and tried to explain the reasons for the different conclusions of previous studies. This helped clarify existing disputes. Second, green technology innovation is a key measure for essentially reducing environmental pollution, but few studies have considered this factor when studying the relationship between political connections and environmental performance. This study explores the mediating role of green technology innovation, which is beneficial to the enrichment of existing research on environmental issues. Furthermore, the public is also very concerned about the pollution behavior and environmental performance of enterprises, and it is an indispensable force for promoting green development. But the previous literature has considered this factor less. Studying the moderating effect of public participation on the relationship between political correlation and environmental performance can advance our knowledge of the subject.

Additionally, our findings have practical implications, providing significant guidance for both the government and enterprises. The government should promote companies to assume environmental responsibility actively. From the perspective of compensation for environmental pollution, enterprises are the main environmental polluters and should be responsible for pollution prevention and control. However, in pursuit of the maximization of benefits, companies will not take the initiative to carry out environmental management that requires a lot of cost. Consequently, proactive environmental policies must be implemented by the government in order to enhance the energy efficiency of enterprises and to reduce their pollutant emissions. On the one hand, strict environmental standards and punishment measures should be formulated to give enterprises pressure and deterrence. On the other hand, enterprises should be provided with economic incentives to take the initiative in environmental governance by introducing environmental taxes and subsidies, etc. The government's support for environmental protection and the guidance of relevant policies are vital driving forces to help enterprises undertake environmental responsibility.

Enterprises should actively participate in green technology innovation. Pollution control measures can be divided into two categories: governing after the event and preventing from the source. To purify the pollutants generated, enterprises construct pollution treatment facilities. This belongs to the end-of-pipe treatment, intending to minimize the harm of pollution. Yet pollution has been caused to a certain extent. However, green technology innovation is the way to prevent pollution from the source. Product innovation and process improvement in relation to the environment are important manifestations of green technology innovation, and they can essentially improve energy efficiency and 
reduce the degree of pollution emissions. Green technology innovation means that enterprises take the initiative to engage in environmental management and control pollution from the source. This plays a critical role in improving corporate environmental performance and reducing environmental pollution.

The positive role of public participation in corporate environmental governance should be strengthened. Public participation in environmental protection can act as a significant method of environmental sustainability. Increased public awareness of environmental protection provides an opportunity for it. With the development of new media and big data, the influence of public participation on corporate environmental management is largely increasing. However, companies usually neglect the influence of their pollution behavior on the environment on account of the absence of sound laws and any comprehensive supervision. Under these circumstances, public supervision is an indispensable force in promoting environmental protection and green development. Additionally, public participation in environmental protection will gradually become a social force, urging companies to improve their environmental performance.

Green development requires the joint participation of the government, enterprises and the public. The public is the fundamental force for promoting green and sustainable development. As the leading force, the government is supposed to assume responsibility for perfecting policies and laws related to the environment. Furthermore, enterprises should proactively undertake environmental responsibility and disclose environmental information, which not only facilitates public supervision, but also enhances their corporate reputation.

Author Contributions: The authors contributed equally to this work. All authors read and approved the final manuscript.

Funding: This research was funded by the National Natural Science Foundation of China, grant number 71702118; and the Chengdu Social Science Planning Project, grant number 2018R13.

Conflicts of Interest: The authors declare no conflict of interest.

\section{References}

1. Lee, K.H.; Cin, B.C.; Lee, E.Y. Environmental Responsibility and Firm Performance: The Application of an Environmental, Social and Governance Mode. Bus. Strat. Environ. 2016, 25, 40-53. [CrossRef]

2. Gabler, C.B.; Panagopoulos, N.; Vlachos, P.A.; Rapp, A. Developing an environmentally sustainable business plan: An international B2B case study. Corp. Soc. Responsib. Environ. Manag. 2017, 24, 261-272. [CrossRef]

3. Dieleman, M.; Boddewyn, J.J. Using Organization Structure to Buffer Political Ties in Emerging Markets: A Case Study. Organ. Stud. 2012, 33, 71-95. [CrossRef]

4. Lin, H.; Zeng, S.X.; Ma, H.Y.; Chen, H.Q. How Political Connections Affect Corporate Environmental Performance: The Mediating Role of Green Subsidies. Hum. Ecol. Risk Assess. 2015, 21, 2192-2212. [CrossRef]

5. Zhang, C. Political Connections and Corporate Environmental Responsibility: Adopting or Escaping? Energ. Econ. 2017, 68, 539-547. [CrossRef]

6. Ye, C.G.; Wang, Z.; Wu, J.F. Corporate Governance, Political Connection and Environmental Performance. Contemp. Econ. Manag. 2016, 38, 19-25.

7. Wang, X.Y.; Wang, L. State-enterprise relation, local economic priority, and corporate environmental responsibility. Appl. Econ. 2019, 51, 995-1009. [CrossRef]

8. Philipp, P.; Oscar, W. Theorising Global Environmental Governance: Key Findings and Future Questions. Millennium-J. Int. St. 2015, 43, 684-705.

9. Harrington, E.; Hsu, D. Roles for government and other sectors in the governance of green infrastructure in the U.S. Environ. Sci. Policy 2018, 88, 104-115. [CrossRef]

10. Sakkthivel, A.M. Investigating public awareness and perception towards environmental protection and waste management practices - evidences from emerging economies. Int. J. Environ. Waste Manag. 2016, 17, 216. [CrossRef]

11. Walker, H.; Sinclair, A.J.; Spaling, H. Public participation in and learning through SEA in Kenya. Environ. Impact Assess. 2014, 45, 1-9. [CrossRef] 
12. Yang, L.; Zhang, D.L.; Jia, Y.D. Public participation, environmental regulation and enterprise environmental protection investment - based on the empirical evidence of China's a-share heavy pollution industry. Financ. Account. Mon. 2018, 12, 32-40.

13. Gabler, C.B.; Richey, R.G., Jr.; Rapp, A. Developing an eco-capability through environmental orientation and organizational innovativeness. Ind. Market. Manag. 2015, 45, 151-161. [CrossRef]

14. Albort-Morant, G.; Leal-Rodríguez, A.L.; De Marchi, V. Absorptive capacity and relationship learning mechanisms as complementary drivers of green innovation performance. J. Knowl. Manag. 2018, 22, 432-452. [CrossRef]

15. Shi, Y.D.; Zhu, P.Y. The impact of organisational ageing and political connection on organisation technology innovation: an empirical study of IT industry and pharmaceutical industry in China. Asian J. Technol. Innov. 2014, 22, 234-251. [CrossRef]

16. Zona, F., Sr.; Gomez-Mejia, L.R.; Withers, M.C. Board Interlocks and Firm Performance: Toward a Combined Agency-Resource Dependence Perspective. J. Manag. 2018, 44, 589-618. [CrossRef]

17. Shirodkar, V.; Mohr, A.T. Resource Tangibility and Foreign Firms' Corporate Political Strategies in Emerging Economies: Evidence from India. Manag. Int. Rev. 2015, 55, 801-825. [CrossRef]

18. Adomako, S.; Danso, A. Regulatory environment, environmental dynamism, political ties, and performance. J. Small Bus. Enterp. Dev. 2014, 21, 212-230. [CrossRef]

19. Johnson, S.; Mitton, T. Cronyism and capital controls: Evidence from Malaysia. J. Financ. Econ. 2003, 67, 351-382. [CrossRef]

20. Puck, J.F.; Rogers, H.; Mohr, A.T. Flying under the radar: foreign firm visibility and the efficacy of political strategies in emerging economies. Int. Bus. Rev. 2013, 22, 1021-1033. [CrossRef]

21. Dinç, I.S. Politicians and banks: Political influences on government-owned banks in emerging markets. J. Financ. Econ. 2005, 77, 453-479. [CrossRef]

22. Halme, M.; Korpela, M. Responsible Innovation Toward Sustainable Development in Small and Medium-Sized Enterprises: A Resource Perspective. Bus. Strat. Env. 2014, 23, 547-566. [CrossRef]

23. Latan, H.; Chiappetta Jabbour, C.J.; Beatriz, L.D.S.J.; Wamba, S.F.; Shahbaz, M. Effects of environmental strategy, environmental uncertainty and top management's commitment on corporate environmental performance: The role of environmental management accounting. J. Clean. Prod. 2018, 180, 297-306. [CrossRef]

24. Vladimirov, Z. SME Innovations and Performance: The Mediating Role of Product Innovation. Int. Rev. Entrep. 2016, 14, 209-234.

25. Fernando, S.; Lawrence, S. Theoretical framework of CSR practices: integrating legitimacy theory, stakeholder theory and institutional theory. J. Theor. Account. Res. 2014, 10, 149-178.

26. Yarahmadi, M.; Higgins, P.G. Motivations towards environmental innovation: A conceptual framework for multiparty cooperation. Eur. J. Innov. Manag. 2012, 15, 400-420. [CrossRef]

27. Barbara, C.; Tomaž, C.; Janez, P.; Igor, I. Environmental strategy and its implementation: What's in it for companies and does it pay off in a posttransition context? J. East Eur. Manag. Stud. 2018, 23, 55-88.

28. Bansal, P. Evolving sustainably: A longitudinal study of corporate sustainable development. Strat. Manag. J. 2005, 26, 197-218. [CrossRef]

29. Kumar, A.; Cantor, D.E.; Grimm, C.M.; Hofer, C. Environmental management rivalry and firm performance. J. Strategy Manag. 2017, 10, 227-247.

30. Lin, H.; Zeng, S.X.; Ma, H.Y.; Chen, H.Q. Does commitment to environmental self-regulation matter? An empirical examination from china. Manag. Decis. 2015, 53, 932-956. [CrossRef]

31. David, M.; Sinclair-Desgagné, B. Pollution abatement subsidies and the eco-industry. Environ. Resour. Econ. 2010, 45, 271-282. [CrossRef]

32. Wang, K.; Zhang, H.M.; Tsai, S.B.; Wu, L.D.; Xue, K.K.; Fan, H.J.; Zhou, J.; Chen, Q. Does a Board Chairman's Political Connection Affect Green Investment?-From a Sustainable Perspective. Sustainability 2018, 10, 582. [CrossRef]

33. Morgan, G. China's Pollution Woes Fuelled by Corruption; The Globe and Mail, 2013. Available online: https:/ / www.theglobeandmail.com/report-on-business/international-business/asian-pacific-business / chinas-pollution-woes-fuelled-by-corruption/article15481617/ (accessed on 20 January 2019). 
34. Cho, C.H.; Dennis, M.P.; Robin, W.R. Corporate Political Strategy: An Examination of the Relation between Political Expenditures, Environmental Performance, and Environmental Disclosure. J. Bus. Ethics 2006, 67, 139-154.

35. Liu, Z.Q.; Li, J.; Zhu, H.; Cai, Z.Y.; Wang, L.N. Chinese firms' sustainable development-The role of future orientation, environmental commitment, and employee training. Asia Pac. J. Manag. 2014, 31, 195-213. [CrossRef]

36. Saifullah, M.K.; Kari, F.B.; Ali, M.A. Linkage between Public Policy, Green Technology and Green Products on Environmental Awareness in the Urban Kuala Lumpur, Malaysia. J. Asian Financ. Econ. Bus. 2017, 4, 45-53. [CrossRef]

37. Li, W.X.; Higgins, P. Controlling local environmental performance: An analysis of three national environmental management programs in the context of regional disparities in China. J. Contemp. China 2011, 22, 409-427. [CrossRef]

38. Guo, J.L.; Li, J. Political Connections, Official Promotion, and Corporate Environmental Investment: Evidence from Chinese Listed Companies. Friends Account. 2018, 18, 78-82.

39. Khwaja, A.I.; Mian, A. Do lenders favor politically connected firms? Rent Provision in an Emerging Financial Market. Q. J. Econ. 2005, 120, 1371-1411. [CrossRef]

40. Nanda, R.; Rhodes-Kropf, M. Investment cycles and startup innovation. J. Financ. Econ. 2013, 110, 403-418. [CrossRef]

41. Lin, H.; Zeng, S.X.; Ma, H.Y.; Qi, G.Y.; Tam, V.W.Y. Can political capital drive corporate green innovation? Lessons from China. J. Clean. Prod. 2014, 64, 63-72. [CrossRef]

42. Burki, U.; Ersoy, P.; Dahlstrom, R. Achieving triple bottom line performance in manufacturer-customer supply chains: Evidence from an emerging economy. J. Clean. Prod. 2018, 197, 1307-1316.

43. Albort-Morant, G.; Leal-Millan, A.; Cepeda-Carrion, G. The antecedents of green innovation performance: a model of learning and capabilities. J. Bus. Res. 2016, 69, 4912-4917. [CrossRef]

44. Singh, M.P.; Chakraborty, A.; Roy, M. The link among innovation drivers, green innovation and business performance: Empirical evidence from a developing economy. World Rev. Sci. Technol. Sustain. Dev. 2016, 12, 316-334. [CrossRef]

45. Fernandez-Gago, R.; Cabeza-Garcia, L.; Nieto, M. Independent directors' background and CSR disclosure. Corp. Soc. Responsib. Environ. 2018, 25, 991-1001.

46. Guan, W. Political Competency, Political Correlation and Corporate Social Responsibility Performance: Empirical Data from Shanghai Stock Exchange A-share Listed Companies from 2011 to 2014. Commun. Financ. Account. 2016, 24, 85-90.

47. Zhen, M.R.; Li, L. An Evolutionary Game Analysis about Enterprise Pollution Governance Based on Public Participation. Ind. Eng. Manag. 2017, 22, 144-151.

48. Kleindorfer, P.R.; Singhal, K.; Van Wassenhove, L.N. Sustainable operations management. Prod. Oper. Manag. 2005, 14, 482-492. [CrossRef]

49. Montabon, F.; Sroufe, R.; Narasimhan, R. An examination of corporate reporting, environmental management practices and firm performance. J. Oper. Manag. 2007, 25, 998-1014. [CrossRef]

50. Matos, S.; Hall, J. Integrating sustainable development in the supply chain: the case of sustainable development in the oil and gas and agricultural biotechnology. J. Oper. Manag. 2007, 25, 1083-1102. [CrossRef]

51. Muhammad, N.; Scrimgeour, F.; Reddy, K.; Abidin, S. The relationship between environmental performance and financial performance in periods of growth and contraction: Evidence from Australian publicly listed companies. J. Clean. Prod. 2015, 102, 324-332. [CrossRef]

52. Berrone, P.; Cruz, C.; Gomez-Mejia, L.R.; Larraza-Kintana, M. Socioemotional Wealth and Corporate Responses to Institutional Pressures: Do Family-Controlled Firms Pollute Less? Adm. Sci. Q. 2010, 55, 82-113. [CrossRef]

53. Clarkson, P.M.; Li, Y.; Richardson, G.D.; Vasvari, F.P. Revisiting the relation between environmental performance and environmental disclosure: An empirical analysis. Account. Organ. Soc. 2008, 33, 303-327.

54. Clarkson, P.M.; Overell, M.B.; Chapple, L. Environmental reporting and its relation to corporate environmental performance. Abacus 2011, 47, 27-60. [CrossRef]

55. Walls, J.L.; Berrone, P.; Phan, P.H. Corporate governance and environmental performance: Is there really a link? Strat. Manag. J. 2012, 33, 885-913. [CrossRef] 
56. Turban, D.B.; Greening, D.W. Greening. Corporate Social Performance and Organizational Attractiveness to Prospective Employees. Acad. Manag. 1997, 40, 658-672. [CrossRef]

57. Jacobs, B.W.; Singhal, V.R.; Subramanian, R. An empirical investigation of environmental performance and the market value of the firm. J. Oper. Manag. 2010, 28, 430-441. [CrossRef]

58. Meng, X.H.; Zeng, S.X.; Shi, J.J.; Qi, G.Y. The relationship between corporate environmental performance and environmental disclosure: An empirical study in China. J. Environ. Manag. 2014, 145, 357-367. [CrossRef] [PubMed]

59. Faccio, M.; Masulis, R.W.; Mcconnell, J.J. Political Connections and Corporate Bailouts. J. Financ. 2006, 61, 2597-2635. [CrossRef]

60. He, X.G.; Zhang, Y.F.; Lian, Y.L.; Lv, F.F. Political Ties and Firm Value_—An Empirical Study in China. China Ind. Econ. 2013, 1, 103-115.

61. Wissal, B.A.; Lubica, H.; Jean-Michel, S. External knowledge sources, green innovation and performance. Technol. Forecast. Soc. 2018, 129, 210-220.

62. Li, D.Y.; Zhao, Y.N.; Zhang, L.; Chen, X.N. Impact of quality management on green innovation. J. Clean. Prod. 2017, 170, 462-470. [CrossRef]

63. Brunnermeier, S.B.; Cohen, M.A. Determinants of environmental innovation in US manufacturing industries. J. Environ. Econ. Manag. 2003, 45, 278-293. [CrossRef]

64. Lee, K.H.; Min, B. Green R\&D for eco-innovation and its impact on carbon emissions and firm performance. J. Clean. Prod. 2015, 108, 534-542.

65. Ganda, F. Green research and development (R\&D) investment and its impact on the market value of firms: evidence from South African mining firms. J. Environ. Plan. Manag. 2018, 61, 515-534.

66. Cormier, D.; Magnan, M. The economic relevance of environmental disclosure and its impact on corporate legitimacy: An empirical investigation. Bus. Strat. Environ. 2015, 24, 431-450. [CrossRef]

67. Guo, Y.Y.; Xia, X.N.; Zhang, S.; Zhang, D.P. Environmental Regulation, Government R\&D Funding and Green Technology Innovation: Evidence from China Provincial Data. Sustainability 2018, 10.

68. Zhang, T. The Effect of Public Participation on Environmental Governance in the Perspective of New Media-An Empirical Analysis Based on Panel Data of Provincial Pollutants in China. Chin. Public Adm. 2018, 9, 79-85.

69. Wen, Z.L.; Ye, B.Y. Analyses of Mediating Effects: The Development of Methods and Models. Adv. Psychol. Sci. 2014, 22, 731-745. [CrossRef]

70. Baron, R.; Kenny, D. The Moderator-mediator Variable Distinction in Social Psychological Research: Conceptual, Strategic, Statistical Considerations. J. Pers. Soc. Psychol. 1986, 51, 1173-1182. [CrossRef] [PubMed]

71. Wen, Z.L.; Hou, J.T.; Zhang, L. Comparison and application of moderation effect and mediation effect. Acta Psychol. Sin. 2005, 37, 268-274.

72. Charl, V.; Naiker, V. The Effect of Board Characteristics on Firm Environmental Performance. J. Manag. 2011, $37,1636-1663$.

73. Li, L.; Xia, X.H.; Chen, B.; Sun, L.X. Public participation in achieving sustainable development goals in China: Evidence from the practice of air pollution control. J. Clean. Prod. 2018, 210, 499-506. [CrossRef]

74. Kyriakopoulos, G.; Kyriakopoulos, G.L. Ecosystems Services Valuation (ESV) Then and Now: A Review. In Advances in Energy Research; Acosta, M.J., Ed.; Nova Science Publishers: New York, NY, USA, 2017; Volume 27, pp. 1-61.

(C) 2019 by the authors. Licensee MDPI, Basel, Switzerland. This article is an open access article distributed under the terms and conditions of the Creative Commons Attribution (CC BY) license (http://creativecommons.org/licenses/by/4.0/). 